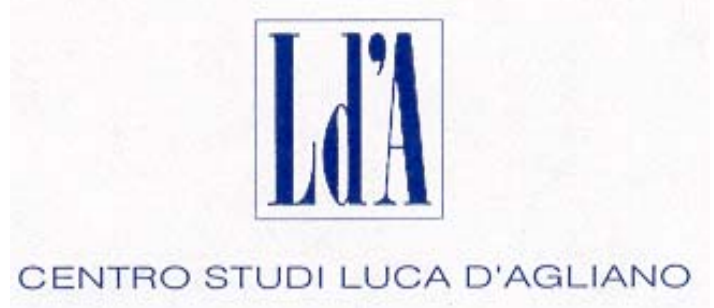

WWW.DAGLIANO.UNIMI.IT

\author{
CENTRO STUDI LUCA D'AGLIANO \\ DEVELOPMENT STUDIES WORKING PAPERS
}

N. 200

March 2005

\title{
Attracting Foreign Direct Investments in Europe: are Italian Regions Doomed?
}

\author{
Roberto Basile* \\ Luigi Benfratello** \\ Davide Castellani***
}

* Isae, Rome and University of Macerata

** University of Turin and Ceris-CNR, Turin

*** University of Urbino and Centro Studi Luca d'Agliano 


\title{
Attracting Foreign Direct Investments in Europe: are Italian Regions Doomed?*
}

\author{
Roberto Basile (Isae, Rome and University of Macerata) \\ Luigi Benfratello (University of Turin and Ceris-CNR, Turin)" \\ Davide Castellani (University of Urbino and Centro Studi Luca d'Agliano)`
}

\begin{abstract}
During the nineties, Europe became a major recipient of FDIs but Italian regions have been largely excluded from this process. Was it due to their characteristics, or were Italian regions 'doomed' by a negative country effect? In this paper we address this issue by estimating the determinants of multinational firms' location choices in $52 \mathrm{EU}$ regions. We find that Italian regions indeed attracted significantly less than their observable potential, and that this could be explained by the inefficiency of the bureaucratic apparatus and of the legal system. The effect of taxes is instead strongly sensitive to the inclusion of agglomeration variables and is asymmetric across regions.
\end{abstract}

JEL Codes: F23, C35, O52

Keywords: multinational firms, location choices, Italy, institutions and policies, negative binomial regression

\footnotetext{
* This work has been promoted and financed by Centro Studi Luca d'Agliano. We wish to thank Giorgio Barba Navaretti and Alessandro Sembenelli for helpful discussions, Marina Di Giacomo, Marco Da Rin and Pasquale Capretta for providing us with some of the data used in this paper, and Laura Anselmi for research assistantship.

•r.basile@isae.it

• benfratello@econ.unito.it

^ castellani@uniurb.it
} 


\section{Introduction}

Foreign direct investments (FDI) in Europe have grown substantially over the last decade, but Italian regions accounted for a very small portion of such increase. This finding rises two questions: i) why did Italian regions attract such a low number of foreign investors?; ii) was it a regional or a country problem?

One explanation for this pattern could be that the characteristics of Italian regions were not attractive to foreign multinationals. In other words, Italian regions might have a low potential to attract FDI so that they have indeed received the 'right' amount of investments given their observable characteristics. This line of reasoning has been put forward in a recent study on the attractiveness of Italy to foreign multinationals, which highlighted that Italian regions and provinces score very low on all the main determinants of FDI attraction, relative to the leading European areas (SiemensAmbrosetti, 2003).

A different, although not alternative, explanation is that Italian regions might have been 'doomed' by sharing common national policies and institutions (such as tax regimes, efficiency of bureaucracy, degree of labour market regulation and effectiveness of the legal and property right protection system) which discouraged foreign firms to locate their plants in Italy. This view follows a recent stream of crosscountry studies which have addressed the role of institutional and policy characteristics as determinants of inward FDI (see, e.g., Nicoletti et al., 2003). ${ }^{1}$ Along these lines, a few recent surveys carried out among investors and opinion makers have suggested that Italy underperforms with respect to other EU countries in the characteristics of the labour market institutions, the quality and efficiency of the public administration and of the legal system, the fiscal burden on companies, and other national institutional aspects (Committeri, 2004; Business International, 2001). Consistently, in a recent paper, Basile, Castellani and Zanfei (2003) have analyzed location choices of multinational firms in EU regions and have found that profits foreign firms extract from their investments in Italian regions are positively correlated. One way to interpret this

\footnotetext{
${ }^{1}$ The question whether Italian regions are doomed recalls a paper written by Nicoletti G. (2002), where the author underlines that "Italy is an outlier among OECD economies when it comes to institutions" (p. 129). He argues that institutional settings in product and labour markets have determined a situation in which this country has relatively low domestic competitive pressures, a distorted industry structure, and unsatisfactory performance in attracting FDI flows.
} 
result is that a common element which affects the attractiveness of all Italian regions which they call the 'country effect'.

We use the number of new foreign affiliates, disaggregated by the 52 NUTS 1 regions of the 5 largest EU countries and by the 20 2-digits SIC manufacturing industries, as a proxy for inward FDI in the 1991-1999 period to extend Basile et al. (2003) results. In particular, we contribute to the above discussion by addressing three questions. First, we model the potential attractiveness of EU regions in terms of their main observable characteristics and investigate whether Italian regions attract more or less than their potential. In other words, we ask whether a EU region with the same characteristics of an Italian region is likely to attract a different amount of FDI. Second, we evaluate the impact of some national policy and institutional characteristics on the attractiveness of regions and we assess to what extent such factors help explaining the Italian specificity. Third, we will simulate the relative contribution of regional and national variables to FDI in Italian regions. This exercise helps us assessing to what extent the low attractiveness of Italian regions during the nineties was the result of specific regional characteristics or of countrywide factors.

Our results suggest that indeed Italian regions are 'doomed' by a negative country effect which, according to some of our estimates reduces the attractiveness of Italian regions to foreign investors by some $40 \%$. In other words, a region 'within the Italian borders' would attract $40 \%$ less multinational firms than a region with similar observable characteristics (i.e. a similar inward FDI potential) in any of the other 4 EU country in our sample. This lower attractiveness seems to be associated with some national institutional characteristics. In particular the efficiency of bureaucracy and the ability of the legal system to adequately enforce property rights play a key role in attracting FDI, while tax competition does not appear to be a very effective policy measure, in presence of significant agglomeration forces. However, national variables can have some asymmetric effect on Italian regions, and it seems that, for example, reducing corporate taxes, as well as the tax wedge on labour might have some positive impact on FDI, although limited to Southern regions. Finally, some simulations suggest that an increase in inward FDI could be achieved though policy intervention on some regional variables, but the order of magnitude of such effect seems much lower than the one obtained by removing the national 'dooming' effect. 
This paper is not the first one that analyses location choices of multinational firms in Italy. Some other works have addressed the question of why some regions and provinces attract more FDI than other regions within Italy (Mariotti and Piscitello, 1995; Basile, 2002 and 2004; Bronzini, 2004). However, in the present work we frame the choice of whether to locate in Italy in the broader context of locating in the EU. In other words, we model the decision process of a firm which plans to carry out some foreign production in Europe and has to choose the location of such an activity. In this perspective, within an integrated economic space, such as the EU, regions belonging to different countries may well compete to attract foreign investments, therefore the analysis of the determinants of location within single countries might overlook such inter-country competition. Along the same lines, the focus on a single country does not allow one to evaluate the contribution of national versus regional factors to location of FDI. This issue can be particularly relevant for targeting an appropriate policy to attract foreign multinationals. In fact, in recent years regional policies have become very important in the context of FDI policy and investment promotion agencies have been established in many regions, in Italy as well as in other EU countries. However, to the extent that regional potential is doomed by national policy and institutions, one may wonder whether it would be more efficient to carry out such a policy at the country level.

This paper also relates to a number of works on cross-country determinants of FDI, which focus on the role of institutional characteristics and national policy, but are not able to assess the role of regional diversity within countries. The combined emphasis on national and regional determinants comes at the cost of a limited variety in country heterogeneity (relative to cross-country studies) and a more aggregated regional analysis (relative to single country location studies).

The rest of the paper is organized as follows. Section 2 describes the relative performance of Italian regions in attracting FDI in Europe, and reports new evidence in favour of the existence of a country effect which might have hindered new foreign entries in Italian regions. Section 3 focuses on the role played by national institutional characteristics, such as efficiency in public administration, labor market regulation, legal system and property right protection, as well as labor and corporate taxation, in determining such a country effect. In particular, we first provide a brief review of the 
literature on FDI and institutions; then, some descriptive evidence on the relative position of Italy in the characteristics of national policies and institutions is reported, and finally an econometric analysis of the impact of national policy variables on the location of foreign multinationals in EU regions is performed, stressing also the existence of regional asymmetric effects. Sections 4 illustrates the results of simulations where we investigate how much would FDI rise (or drop) should some characteristics of Italian regions reach the EU average. Section 5 concludes the paper.

\section{Location of foreign multinationals in Europe: are Italian regions doomed?}

During the nineties, the EU has attracted a large share of world's FDI flows, which accounted for a significant proportion of total investment in the area. As Figures 1 and 2 suggest, about $40 \%$ of world's FDI has been directed towards EU countries in the 1991-1999 period, accounting for a share of gross-fixed capital formation (GFCF henceforth) which has increased from $6.2 \%$ in 1991 to $28.5 \%$ in 1999 . However, this increasing inflow of FDI has not been equally distributed across countries and regions. In particular, among the largest countries, Italy turned out to attract a persistently lower share of FDI flows. Over the 1991-1999 period, FDI accounted only for $1.8 \%$ of the Italian GFCF, while the EU average has been above 9\%. By the late 90s the lag of Italy has become even larger: in 1999 the share of FDI on GFCF was 3.1\% in Italy, while in Spain, Germany, and France it reached $10.9 \%, 12.4 \%$ and $17.2 \%$ respectively, not to mention the United Kingdom where FDI inflows accounted for $34.9 \%$ of GFCF. The regional distribution of FDI looks even more unequal. Using a new dataset (the Elios dataset described in Appendix 1) on the location choices of foreign affiliates in Europe, we map the regional distribution of multinational manufacturing firms established in Europe in the 1991-1999 period (see Figure 3). During the period considered, the number of new foreign affiliates was concentrated in the core regions of France, Germany, and the UK, alongside with Cataluna and Comunidad de Madrid in Spain and Lombardy in Italy, whereas peripheral regions attracted a considerably lower share of multinationals. The peculiarity of Italy emerged also in this context: while Lombardy attracted a considerable number of foreign firms, all other Italian regions were 
characterised by very few newly established subsidiaries. No other EU country showed such a uniformly distributed performance. In other words, this simple descriptive analysis is consistent with the idea that a 'country effect' might have lowered the attractiveness of (almost) all regions within the Italian national boundaries.

Figure 1, 2 and 3 about here

A more robust evidence on a 'country effect' in the case of Italian regions has been provided by Basile et al. (2003), who fitted a nested logit model on an extended version of the dataset used in this paper, to evaluate whether national boundaries affect location decisions and to what extent multinational firms consider regions belonging to different countries as close substitutes. The analysis provided empirical support to the view that country boundaries do not matter (i.e. multinational firms consider regions across countries as closer substitutes than regions within national boundaries) with the exception of Italy. In fact, their results suggest that foreign firms take their location decision on a presumption that investments in Italian regions would yield systematically lower profits than investments in regions from other countries sharing similar observable characteristics. Such a 'country effect' appeared particularly strong in the case of US multinationals. Thus, a relatively advanced region in Italy such as, for example, Emilia Romagna might be perceived by US MNEs as more similar to Italy's Mezzogiorno than, for example, to Baden-Wurttenberg.

In this paper we go beyond Basile et al. (2003) findings by testing whether or not Italian regions indeed attracted less FDI than their potential would suggest and whether national characteristics can explain this result. To this end, we counted new establishments in each of 52 NUTS 1 regions by sector (2-digits SIC) over three consecutive periods in the 90s (1991-1993, 1994-1996, 1997-1999). Since the dependent variable is a count, varying across regions, sectors and time, we estimate our model as a negative binomial and we use random effect panel data techniques (see Appendix 2). 


\subsection{The role of regional characteristics in attracting FDI in EU regions}

In Table 1 we first assess the role of regional characteristics in attracting FDI in EU regions (column 1). The key variables that the literature suggests as the main determinants of location of foreign firms have the expected signs and are significantly different from zero (see the Appendix 1, Tables A.1 and Table A.2, for a list of variables, data sources, and descriptive statistics). In particular, regional market size and market potential (higher for regions which are close to large markets) have a strong impact on location, confirming the 'market access' hypothesis. Agglomeration economies, stemming from the overall number of firms and from foreign firms in a region-sector, have the expected positive and significant sign, whereby corroborating the prediction of New Economic Geography models. High wages seem to discourage FDI, while high $R \& D$ intensity and schooling rate attract foreign investors. The extent of transport infrastructures, which can be thought also as an indicator of regional policy (although not under complete control of regional institutions), is also an important determinant of location.

- Table 1 about here -

\subsection{Do Italian regions attract less FDI than their potential?}

After defining the main determinants of the regional potential attractiveness to foreign investors, we then investigate whether Italian regions indeed attract less than their EU counterparts with similar observable characteristics (column 2). In particular, we augment our basic model introducing dummies for macro-areas in Italy: NorthWest (split between Lombardy and other North-West regions), North-East, Centre, and South. We find strong evidence that, with the exception of Lombardy, the region where around one half of multinationals in Italy locate (ICE, 2004), all Italian macro-areas attract significantly less than their potential would suggest (results for the single NUTS 1 regions are qualitatively similar and are not shown just to save space).

This result might depend on the fact that we actually did not measure the potential attractiveness of regions accurately, and the area dummy picks up such 
unobserved regional characteristics. ${ }^{2}$ Alternatively, the regional dummy could be absorbing the negative effect of 'being an Italian region'. In fact, the results reported in column 3, where a single dummy for all Italian regions suggest that overall, they attract considerably less $(39 \%)$ than their EU counterparts with similar characteristics. ${ }^{3}$ In other words, it could be that the lower attractiveness of Italian regions does not depend on some regional characteristics which are missing from our specification (e.g. the presence and effectiveness of investment promotion agencies), but on a country effect which depresses investment in all Italian regions.

\subsection{Are Italian regions doomed?}

In Table 1 we want to test the hypothesis that Italian regions are doomed by the fact of being located in Italy. We test this hypothesis by looking at the regional effect after controlling for the country effect. In other words, once controlled for the fact that 'being within the Italian borders' reduces the overall potential of a region, we ask whether Italian regions attract less than their counterparts with similar characteristics. Columns 4-8 suggest that once the fact that Italian regions are doomed is accounted for, Northern and Southern regions do not attract a significantly different number of investments as their observable characteristics would predict, Lombardy attracts even more than its observable potential and only in the case of Central regions we observe that the number of foreign investments is actually significantly lower than it would be expected from the regional potential.

In turn, this finding opens the question of why Italian regions are doomed and which country characteristics determine the overall lower attractiveness. Theoretical literature and previous surveys seem to point to the national institutional framework and country-level public policy.

\footnotetext{
${ }^{2}$ It is, however, important to remind that we use a random effect model, which controls for unobserved heterogeneity of each region/sector.

${ }^{3}$ In a negative binomial regression model, the percentage change in the dependent variable due to a dummy variables taking a value of 1 instead of 0 is measured by $[\exp (\beta)-1]^{*} 100$.
} 


\section{The role of national institutions in MNCs' location choices}

\subsection{Institutions and FDI: theoretical and empirical background}

Several cross-regional studies have investigated the role of regional policies in affecting location choices of multinational firms. In particular, this literature has emphasized the role of regional promotion incentives (such as financial, tax, and laborpromotion incentives) and of public infrastructures in affecting a foreign firm's cost function and thus its location decision. ${ }^{4}$ On the contrary, due to the lack of data, these studies have disregarded the effect of national policies and national institutional settings on regions' performance in attracting foreign investors. However, it is well recognized that country specific policies and institutional factors can have important symmetric or even asymmetric effects on the regional distribution of FDI.

Conversely, the effect of national institutional variables on inward FDI has been widely analysed in cross-country studies, which recognise that the host-country institutions and policies affect the entry decision of multinational firms. ${ }^{5}$ Following the existing literature, these variables can be grouped in six categories: 1) labour market arrangements, 2) corporate taxation, 3) bureaucratic efficiency and corruption, 4) legal system and intellectual property right protection, 5) product market regulation and 6) openness to FDI. However, as Nicoletti et al. (2003) point out, product market regulations that restrict competition and barriers to foreign investment in OECD countries are confined mainly to energy and marketable service industries. Since our study is restricted to manufacturing industries, we do not consider these particular institutional aspects in the following analysis.

1) Labour-market arrangements - A wide set of policies and institutions affect the functioning of the labour market impinging on FDI transactions. Generally speaking, empirical studies focus on the tightness of the employment protection

\footnotetext{
${ }^{4}$ See, for examples, Head C.K., Ries J.C. and Swenson D.L. (1999), Devereux M., Griffith R. and Simpson H. (2003), Crozet M., Mayer T. and Mucchielli M. (2003), Barrios S., Gorg H. and Strobl E. (2003). As for examples of analyses focussing on public infrastructure see Basile R. (2004) and Wheeler D. and Mody A. (1992).

${ }^{5}$ In principle, causality may run in the other direction so that the actual operation of a foreign firm affects the host-country institutions and policies, especially when the multinational achieves a strong position in the host economy. However, this is more likely to occur in developing countries than in developed countries.
} 
legislation (EPL henceforth), the collective bargaining mechanisms, and the labour income taxation (typically, the tax wedge on labour). Görg (2002), Gross and Ryan (2004), Javorcik and Spatareanu (2005), and Nicoletti et al. (2003) find empirical support to the idea that EPL and labour taxes adversely affect relative returns from investing in a country with a tight regulation, whereby discouraging FDIs. Lee (2003) observes, however, that the effects of EPL and labour income taxation on FDI may depend on the regime of industrial relations in place in each country.

2) Corporate taxation ${ }^{6}$ - The corporate tax system has an obvious theoretical relationship with inward FDI: higher tax rates increase the cost of doing business in a country, whereby reducing the attractiveness of such location. However, the empirical evidence on the impact of the corporate tax rate on inward FDI and foreign firms location choices is mixed (see, e.g., Devereux and Griffith, 1998, 2003; and BénassyQuéré et al., 2000). In fact, a number of issues arise when estimating the effect of tax regimes on international investments. First, the correct measurement of the effective corporate tax rate is not trivial given available data; second, tax schemes differ across countries (i.e. full credit vs. exemption schemes); third, firms might "accept higher taxes if they are associated with better infrastructures or public services" (BénassyQuéré et al., 2000, p. 7), so that tax differences could not matter for location decisions if they simply balance differences in public goods; fourth, and foremost agglomeration forces make tax competition too costly because they can be counteracted only by very large differences in tax rates. In particular, as shown, among others, in Baldwin et al. (2003) and Baldwin and Krugman (2004), agglomeration forces create quasi-rents that can be taxed without inducing delocation.

3) Corruption and bureaucratic efficiency - Corrupt behaviour among government officials is an informal institution that can arise when market economy institutions are underdeveloped, and produces high transaction costs that increase the MNE's costs of doing business in the host country. Such extra-costs decrease the expected profitability of an MNE direct investment and tend to deter foreign investors from starting production in the host country. Recent studies (Wei, 2000; Johnson and Dahlström, 2004) provide empirical evidence of a negative relationship between host-

\footnotetext{
${ }^{6}$ In most European countries, fiscal (tax) policies do not have a regional dimension, since European Community rules consider a regional differentiation in labour and capital taxes as a distortion of competition. Thus, even tax policies must be regarded as national policies.
} 
country corruption and FDI inflows. Hakkala, Norback and Svaleryd (2003), however, observe that the effect of corruption may vary with the composition of the investment flows. A similar effect can be expected to stem from an inefficient bureaucracy. In fact, lengthy and sloppy bureaucratic procedures increase the cost of operating business, reducing the attractiveness of the country to foreign investors.

4) Legal system and intellectual property right protection - The relationship between intellectual property rights (IPR henceforth) protection and FDI is very complex. On the one hand, a weak protection increases the probability of imitation and thus it makes a host country less attractive for foreign investors. On the other hand, strong protection may shift the preference of MNEs from FDI towards licensing. Nicoletti et al. (2003) do not find a robust effect of the lack of IPR protection in the host country on FDI. However, this result might depend on the sample of countries used and on the sector analysed. Javorcik (2004), for example, examines the impact of intellectual property protection on the volume of FDI using a firm-level data set from Eastern Europe and the former Soviet Union and demonstrates that weak protection deters foreign investors in technology-intensive sectors where IPR play an important role.

More generally, the extent to which a country can enforce property rights can be a key determinant of its attractiveness towards foreign investors. In fact, a strong IPR protection system needs to be implemented through an efficient legal system, which ensures that firms can have their contracts, trademarks and patents enforced without entering into exhausting trials lasting several years.

\subsection{Overview of national institutions and policies in the 5 largest EU countries}

Nicoletti (2002) observes that "Italy is an outlier among OECD economies when it comes to institutions" (p. 129). In particular, he emphasizes that product and labour markets are more regulated in Italy than in most of its trading partners, legal rules and their enforcement are relatively weak and that, at the same time, Italy shares broadly similar bargaining arrangements and social policies with many other European countries. He also argues that due to this situation, Italy has relatively little inflow of FDI. 
In this paper, we aim at testing this prediction using data on country policy and institutional settings. The first issue that one needs to take into account when testing the impact of institutions and policies on economic performance is that reliable measures of such characteristics are not easy to find, due to the fact that most of them are not directly observable or are multifaceted concepts which can hardly be captured by a single indicator. Furthermore, the fact that for the present analysis information over the past decade was required (at least three observations for each country over the nineties), a number of surveys which have been carried out only in recent years (such as data from the Economist Intelligence Unit and some OECD data) cannot be used. However, we believe that we were able to collect rather reliable information from four authoritative sources such as the OECD for data on tax wedge on labour, the IFS (Institute for Fiscal Studies) for data on the effective average corporate tax rate, the IMD's World Competitiveness Yearbook for data on labour regulation (in particular, EPL) and on bureaucratic efficiency, and the Global Competitiveness Report (published by the Frazer Institute) for data on the legal system and the IPR protection. Definitions of each variable are reported at the bottom of Table 2, which provides an overview on the different institutional characteristics for the 5 countries in our sample.

- Table 2 about here -

Although there are several dimensions to labour market arrangements (see Nicoletti, 2002, and Lee, 2003), we focus on two specific items, namely the tax wedge on labour and the EPL, which several cross-country studies have shown to be the most important variables impinging inward FDI. Inspection of Table 2 reveals that France, Germany and Italy have higher levels of tax wedge on labour than the United Kingdom and Spain. Moreover, while the UK and Spain maintained the tax wedge quite stable during the period, the other countries raised their taxation level. In particular, the Italian tax wedge increased from an average level of $35.6 \%$ registered in 1991 to $45.4 \%$ registered in 1997.

The IMD data on labour regulation confirm the commonly held view that there are substantial differences between EU economies in hiring and firing restrictions and, in general, in the EPL. To interpret these data, notice that the IMD variables are 
normalised and range from 0 to 10 and that higher values denote less restrictive legislations. Therefore, during the nineties the regulatory environment has been much less strict in the UK than in the other four European countries, while Italian and Spanish labour markets are characterised by the strongest employment protection. Furthermore, while Spain and the UK have improved their position over time, Italy, Germany, and France have scored lower levels during the last part of the nineties. As for Italy, Nicoletti (2002) also observes that while hiring and firing costs for temporary contracts have been partially reduced during the nineties, EPL for both permanent and fixed-term workers remained more restrictive than in the European average.

Differences in fiscal policies among EU countries are also quite remarkable. Table 2 reports IFS data on the effective average corporate tax rate proposed by Devereux and Griffith (2003). ${ }^{7}$ It turns out rather clearly that Italy shares the highest tax rates with Germany but, while for this country a downward trend is observed, in the case of Italy taxes have been rising over the first half of the decade. On the contrary, Spain have steadily reduced its effective average corporate tax rate.

As for bureaucratic efficiency, although important reforms have been carried out in Italy in the 90 s in order to simplify the procedures of public administration, the international comparison based on IMD data confirms that this country scores very low along this dimension. Furthermore, while Spain and the UK show an improvement of their score during the period, Italy, France, and Germany scored a lower level ${ }^{8}$.

Finally, Table 1 reports data on the legal system and the intellectual property right protection retrieved from the Frazer Institute dataset. Like the IMD data, these data range from 0 to 10 and an increase of the indicator correspond to a higher protection. According to this source, Germany had the best legal system throughout the period, while France and the UK improved substantially from 1991 to 1997 . On the

\footnotetext{
${ }^{7}$ Devereux M. and Griffith R. (1999) observed that the evaluation of the impact of fiscal policy on investment choices differ according to the type of investment decision considered. In the case of marginal investment choices (typically, how much to invest, given a diminishing expected return), the impact of tax policies must be measures by an effective marginal tax rate. In the case of discrete investment choices, such as the location decision of multinationals, the impact of tax policies must be measured by an effective average tax rate, which is shown to be equal to a weighted average of an effective marginal tax rate and an adjusted statutory tax rate, where the weights depend on the profitability of the investment (Devereux M. and Griffith R., 2003).

${ }^{8}$ It should be noted that 1991 data was missing and we had to estimate this value using 1994 data. This causes a substantially lower variability of this characteristic over time.
} 
contrary, Italy and Spain scored rather low at the beginning of the nineties and do not show any significant improvement.

Summing up, Table 2 depicts a situation in which several Italian institutions and policies appear quite peculiar, confirming the conclusions of Nicoletti (2002), which was confined to product and labour market institutions. In the following, we extend the econometric analysis of section 2 in order to assess to what extent this peculiar institutional and policy framework can explain the low performance of Italian regions in attracting foreign multinationals. Furthermore, we will be able to investigate whether, once controlled for time invariant country characteristics, institutional and national policy change can explain the changing distribution of FDI flows across EU regions.

\subsection{The role of national institutions for MNCs location in EU regions: regression results}

Table 3 presents the results of 7 regressions, which build on the specification of column 3 in Table 1 and aim at testing the impact of nation-wide policies and institutions on FDI.

- Table 3 about here -

Results broadly support our prior on the impact of the different institutional characteristics on multinational firms' location choices. In particular, when we add our measures of national policy individually to the baseline specification of column 3 in Table 1 (in columns 9-13) we find that higher taxes on labour and a tighter legislation on hiring and firing practices have a negative impact on FDI, whereas efficient bureaucracy and legal system attract foreign multinationals. Lower corporate taxes do not seem to be associated to a significant increase in foreign investments but, as we will show later in this section this might have to do with the fact the tax competition is less effective in presence of strong agglomerative forces.

More interestingly for the purpose of this paper, the magnitude of the coefficient for the dummy identifying Italian regions drops when we control for the nature of the 
legal system and the tightness of labour regulations and becomes even not significantly different from zero when controlling for the efficiency of bureaucracy, suggesting that the various institutional characteristics capture at least part of the Italian specificity.

When we introduce the various country characteristics jointly (column 14), we find that also the combination of country characteristics capture the Italian specificity; however, only legal system and bureaucracy remain significant and with the expected sign. As a robustness check, in column 1 of Table 4, we substitute the dummy for Italian regions with five dummies indicating the geographical area where each Italian region is located and find that, once controlled for national institutional characteristics, these indicators are not significantly different from zero. In other words, results are consistent with the idea that the lower number of foreign investments in Italian regions, relative to other European regions, can be explained by the specificity in institutions and national policies. In particular, the efficiency of the bureaucratic apparatus and of the legal system turn out as two key determinants of attractiveness to foreign investors, and we support the idea that the relative gap of Italy in these dimensions has significantly discouraged multinationals from locating in Italian regions.

The fact that differences in labour and corporate taxes do not explain differences in inward FDI, might seem rather odd, given the importance that fiscal variables play in almost any country policy towards FDI. However, as reported in Bénassy-Quéré et al. (2003) existing evidence on the role of tax competition on FDI is rather mixed, and one recurrent explanation is that in presence of agglomeration forces only very large tax differentials provide the right incentive to delocalise economic activities. This finding is not new in the empirical literature (see, for example, Head, Ries and Swenson, 1999) and is in line with the theoretical predictions of some recent new economic geography models which cast some doubt on the traditional wisdom that producers should move to whichever country (region) has the lowest tax rates, and suggest that agglomeration forces create quasi-rents that can be taxed without inducing delocation (see, e.g., Baldwin et al. 2003; Baldwin and Krugman, 2004). To test for this hypothesis, in column (15) of Table 3 we drop our two measures of agglomeration from the final specification. Results remain qualitatively similar for the regional variables: although some coefficients change in magnitude, as they pick up some of the effects of agglomeration forces, the sign and significance are virtually unchanged. On 
the contrary, as for national policies and institutional characteristics, we observe that now both the corporate tax rate and the tax wedge on labour enter with a negative and very significant sign. In other words, we support the hypothesis that, whenever agglomeration economies play a role in affecting firms' location decisions, tax competition is not the more effective policy measure to affect the attraction of multinational firms.

\subsection{The asymmetric impact of institutions on laggard regions}

The empirical results discussed above allowed us to identify some basic determinants of the weak capability of the Italian system to attract foreign investors and to answer the question of why Italian regions are doomed. However, those results are based on the presumption that national institutions and policies (namely, the tax regimes, the labour market regulation, the legal system and the bureaucratic efficiency) have a symmetric effect on all regions within each country. For instance, these results imply that lowering the corporate tax rate does not affect, on average, foreign firms' decision to invest in Italian regions, or that raising the quality of the legal system or bureaucracy affect homogenously the attractiveness of Northern and Southern areas of the country. However, these effects need not be symmetric across regions.

In fact, the issue of the regional asymmetric effect of national policies is widely discussed in the literature (e.g. Nicoletti, 2002). The basic idea is that whenever significant regional imbalances within a country exists, such as in the Italian case, national policies and institutions, which tend to be designed around the characteristics of the median voter, can create different constraints for laggard regions. For instance, the (high) level of the tax wedge and degree of regulation on the labour market in Italy mainly reflects the economic conditions of the leading (Northern) regions and it is much more inadequate for the development conditions and the location disadvantages of Southern Italy. Similarly, setting a relatively high corporate tax rate across all regions might adversely affect laggard regions which can hardly compensate for this relative cost disadvantage with other locational characteristics. Therefore, we can expect that this situation tends to generate asymmetric effects, i.e. to create a higher constraint for the regional attractiveness of external investments and, thus, for job 
creation in the South. The hypothesis of asymmetric effects can be put forward also for other national policy and institution, including bureaucratic efficiency and the legal system. It is indeed possible that an inefficient bureaucratic apparatus or a weak legal system affects more heavily the FDI attractiveness of a backward region than that of a leading region, just because the latter has some unobserved characteristics which partly compensate the countrywide institutional weakness.

We investigate whether institutional characteristics have asymmetric effects on Italian regions by augmenting the specification of column 1 in Table 4 with interaction terms between Italian regional dummies (Lombardy, the other North-Western regions, the North-East, the Centre and the South) and our five institutional/policy variables. These interactions should capture the extent to which national institutions have a different impact on the attractiveness of different regions. The main (and most robust) result is that, while the high national corporate tax rate does not represent a common factor that helps explain the low attractiveness of Italy as a whole, it can be considered as a location constraint for the South. There is also some (less robust) evidence that a lower tax wedge on labour and a stronger legal system would benefit the South more than the rest of the country and that a weaker labour regulation would be less effective in Lombardia than in the other regions.

- Table 4 about here -

\section{Simulating the impact of the Italian lag on inward FDI}

The final step of our empirical investigation consists in some simulations on the impact that a change in the observable characteristics of Italian regions would have on their attractiveness. On the basis of the estimates from the regressions above, we compute how the predicted number of foreign investments in Italian regions would have changed if some of the regional characteristics had been set to the average level of the other four EU countries. This will provide a rough indication of what would be the impact of a policy intervention aimed at improving regional characteristics to EU standard. However, this exercise will also tell us something about the differential impact of regional vs. national policy. In fact, we know from Table 1 that, given 
observable regional characteristics, Italian regions attract 39\% less than their potential. Therefore, this is our benchmark for the contribution of national characteristics to regional attractiveness. Assessing the contribution of regional characteristics will give us a rough indication of the extent to which the low level of FDI in Italian regions is due to the country effect or to the low regional potential.

Table 5 reports the results of our simulation exercise ${ }^{9}$. The relatively low wages seem to exert a strong influence on Italian ability to attract FDI. In fact, raising the wage bill to the EU average would determine a fall in foreign investments from $4 \%$ in Lombardy to $37 \%$ in Southern regions. Conversely, a sharp increase in FDI flows would occur if Italian regions could manage to raise their R\&D investments and schooling rate and to improve their transport infrastructures. Overall, these simulations suggest that attractiveness of Italian regions could be substantially increased by improving some regional characteristics, such as R\&D activities, education and infrastructures. However, the magnitude of the increase in FDI from these policies turns out as relatively low if compared with the large negative impact of national characteristics.

- Table 5 about here -

\section{Concluding remarks}

This paper tries to shed light on the following question: why, despite the growing importance of FDI in the EU, Italian regions have attracted very few foreign investors over the nineties? We have argued that this might be explained by individual regions' characteristics or by some 'country effect' affecting all Italian regions. Although the two explanation are not necessarily alternative, the first one would suggest that Italian regions have a low potential to attract FDI and they attract the 'right' amount given their characteristics, whereas the second line of reasoning would

\footnotetext{
${ }^{9}$ Simulations have been computed by using the estimated coefficients of a random effect negative binomial regression of our FDI measure on regional and country characteristics, with sector dummies but without country dummies. Details on the methodology can be found in Appendix 2. Table 5 reports simulations for the main regional characteristics. Agglomeration and specialization variables have not been reported as they are regional/sectoral specific and aggregation across sectors posed some problems due to regions with very few FDI in a few sectors.
} 
argue that Italian regions are doomed by the 'country effect' and indeed attract less than their potential.

Using data on location choices of multinational firms in $52 \mathrm{EU}$ regions (in the 5 largest countries) over the 1991-1999 period, we provide strong evidence that Italian regions attract significantly less than their observable characteristics would suggest. Following a growing literature on the role of institutions on FDI, we investigated to what extent this country effect can be explained by national policies and institutions, which might have discouraged foreign firms to locate their plants in Italy. Our findings suggest that an inefficient bureaucracy and a legal system inadequate in ensuring an efficient enforcement of property rights are the main characteristics which explain the low level of FDI in Italian regions as compared with other EU locations. Furthermore, our results support the hypothesis that under significant agglomeration economies, core countries can tax their industry at a higher rate than peripheral countries can, without letting the industry go. For example, the high Italian corporate tax rate cannot be considered as a "common factor" that help explain the low FDI attractiveness of the country as a whole. However, we also have econometric evidence that a high corporate tax rate may be a strong constraint for the Mezzogiorno of Italy while it has no effect for the rest of the country. In other words only the South would be advantaged from a reduction of the corporate tax rate.

This paper therefore suggests that Italian regions discount a strong negative effect stemming from the national institutional and policy framework. One of the implication of this result is that efforts made by regional institutions to improve the attractiveness of their area either by investing in enhancing observable characteristics, such as schooling, R\&D investment, infrastructures and wages, or by improving the perceived attractiveness with image building, promotion and territorial marketing, might reveal as a Sisifo's effort, to the extent that national obstacles depressing investments are not removed. In this perspective, national policy could be more effective in attracting foreign investors. Furthermore, our evidence on asymmetric effects of national policies also raises the question of whether it is appropriate within a country with significant regional imbalances like Italy to have an homogenous corporate tax rate. 


\section{References}

Aizenman J. and Spiegel M.M., Institutional Efficiency and the Investment Share of FDI, Santa Cruz, Department of Economics, UCSC, mimeo, 2004.

Banga R., Impact of Government Policies and Investment Agreements on FDI Inflows, New Delhi, Indian Council for Research on International Economic Relations, Working Paper 116, 2003.

Barrios S., Gorg H. and Strobl E., Multinationals'Location Choice, Agglomeration and Public Incentives, Louvain, Core Discussion Paper 17, 2003.

Basile R., "The Location Determinants of Foreign-Owned Manufacturing Plants in Italy: Preliminary Results", Rivista di Politica Economica, July-August, 2002, p. $62-92$.

Basile R., "Acquisition Versus Greenfield Investment: the Location of Foreign Manufacturers in Italy”, Regional Science and Urban Economics, 34/1, 2004, p. $3-25$.

Basile R., Castellani D. and Zanfei A., "Location choices of multinational firms in Europe: the role of national boundaries and EU policies", Quaderni di Economia, Matematica e Statistica, Urbino, 2003.

Baldwin R. E., Forslid R., Martin P., Ottaviano G.I.P., and Robert-Nicoud F., Economic Geography and Public Policy, Princeton, Princeton University Press, 2003.

Baldwin, R. E. and Krugman P., "Agglomeration, integration and tax harmonization", European Economic Review, 48, 2004, p. 1-23.

Bénassy-Quéré A., Fontagné L. and Lahrèche-Révil A., Foreign Direct Investment and the Prospects For Tax Co-Ordination in Europe, Paris, CEPII, Document de travail 6, 2000.

Bronzini R., Foreign Direct Investment and Agglomeration: Evidence from Italy, Roma, Banca d'Italia, Tema di Discussione 526, December, 2004.

Business International, La capacità di attrazione del Sistema Italia, Roma, 2001. 
Cameron C. and Trivedi P., Regression analysis of count data, Cambridge, Cambridge University Press, 1998.

Committeri M., Investire in Italia? Risultati di una recente indagine empirica, Roma, Banca d'Italia, Temi di discussione 491, March, 2004.

Crozet M., Mayer T., and Mucchielli J.L., How do Firms Agglomerate? A Study of FDI in France, London, CEPR Discussion paper, 3873, 2003.

Dewit G., Görg H. and Montagna C., Should I stay or should I go? Foreign direct investment, employment protection and domestic anchorage, Nottingham, University of Nottingham, mimeo, 2004.

Devereux M. and Griffith R., "Taxes and Location of Production: Evidence from a Panel of US Multinationals", Journal of Public Economics, 68/3, 1998, p. 335367.

Devereux M. and Griffith R., The taxation of discrete investment choices, London, The Institute for Fiscal Studies Working Paper 98/16, 1999.

Devereux M. and Griffith R., "Evaluating tax policy for location decision", International Tax and Public Finance, 10/2, pp. 107-126, 2003.

Devereux M., R. Griffith and Simpson H., Agglomeration, regional grants and firm location, Warwick, University of Warwick and Institute for Fiscal Studies, mimeo, 2003.

Golub S., "Measures of restrictions on inward foreign direct investment for OECD countries", OECD Economic Studies, 1/36, 2003, p. 7-83.

Görg H., Fancy a stay at the Hotel California? Foreign direct investment, taxation and firing costs, Bonn, IZA Discussion Paper 665, 2002.

Gross D.M. and Ryan M., FDI Location and Size. Does Employment Protection Legislation Matter?, Kalamazoo, Department of Economics, Western Michigan University mimeo, 2004.

Hakkala K., Norback P.J. and Svaleryd H., FDI and Corruption. Evidence from Swedish Multinational Firms, Stockholm, Research institute of Industrial Economics, mimeo, 2003. 
Hausman, J, Hall, B. and Griliches Z., "Econometric models for count data with an application to the patents-R\&D relationship", Ecomometrica, 52/4, 1984, p. 909938.

Head C.K., Ries J.C. and Swenson D.L., “Attracting foreign manufacturing: investment promotion and agglomeration", Regional Science and Urban Economics, 29, 1999, p. 197-218.

Hines J.R., "Altered States: Taxes and the Location of Foreign Direct Investment in America”, American Economic Review, 86, 1996, p. 1076-1094.

ICE, Rapporto sul commercio estero 2004, Roma, 2004.

Javorcik B.S., "The composition of foreign direct investment and protection of intellectual property rights: Evidence from transition economies", European Economic Review, 48, 2004, p. 39-62.

Javorcik B.S. and Spatareanu M., Do foreign investors care about labour market regulations?, London, CEPR Discussion Papers 4839, 2005.

Johnson A. and Dahlström T., Bureaucratic Corruption, MNEs and FDI, Jönköping, Jönköping International Business School, mimeo, 2004.

Lee C.S., The Effect of labour market institutions on FDI inflows, Seoul, KIEP Working Papers 03-09, 2003.

Mariotti S. and Piscitello L., "Information Costs and Location of FDIs within the Host Country: Empirical Evidence from Italy", Journal of International Business Studies, 26/4, 1995, p. 815-841.

Nicoletti G., "Institutions, Economic Structure and Performance: Is Italy Doomed?”, in ISAE Annual Report “Monitoring Italy”, January, 2002, p. 129-197.

Nicoletti G., Golub S.S., Haikova D., Mirza D., and Yoo K.Y., “The influence of policies on trade and foreign direct investment", OECD Economic Studies, 1/36, 2003, p. 7-83. 
Siemens-Ambrosetti, Gli indicatori e le politiche per migliorare il Sistema Italia e la sua attrattività positiva, Report available on internet at http://www.siemens.it/ambrosetti/index.html, 2003

Wei S.J., "How Taxing Is Corruption on International Investors?", The Review of Economics and Statistics, 82/1, 2000, p.1-11.

Wheeler D. and Mody A., "International investment location decisions: the case of US firms", Journal of International Economics, 33, 1992, p. 57-76. 


\section{Appendix 1. Data and variables}

The data on inward FDI used in this work is a sample of 5,354 location choices made by multinational firms over the 1991-1999 period in 52 NUTS 1 (Nomenclature of Territorial Units for Statistics) regions in the 5 largest EU countries: France, Germany, Italy, Spain, and UK. The sample is a subset of the Elios (European Linkages and Ownership Structure) database, a project carried out at the University of Urbino. The Elios database collects information retrieved from Dun \& Bradstreet's "Who Owns Whom" and from the Bureau Van Dijk's "Amadeus" directory of firms located in Europe. For each firm the database contains the year of establishment, the ultimate owner, which allowed us to identify foreign-owned multinationals, the primary sector of activity (2-digit SIC code) and the region where firms are registered. Such information is available at various degrees of aggregation in the different countries. To allow for cross-country comparisons we used regional aggregation at NUTS 1 level, available for all countries. The distribution of our sample by countries is remarkably similar to the corresponding distribution of inward FDI over the same period reported by UNCTAD, suggesting that we have a good representation of the various countries.

For the econometric analysis we aggregated our firm-level data by region, sector and time, and we estimated a negative binomial regression model in which the dependent variable is the number of foreign entries in a given NUTS 1 region in a given two-digit SIC manufacturing sector and in three consecutive periods (1991-1993; 1994-1996, 1997-1999) for a total of 3,120 observations (52 regions x 20 sectors x 3 periods). Independent variables have been selected according to the existing literature on location choices of multinational firms, in order to provide the more accurate representation of the potential attractiveness of each region. Table A.1 describes the variables and relative sources whereas Table A. 2 presents the descriptive statistics. 
Table A.1. - Variable List and Description, regional variables

\begin{tabular}{|c|c|c|c|c|}
\hline & Variables & Description & Source & Type \\
\hline & $\begin{array}{c}\text { Market } \\
\text { Size }\end{array}$ & Log (Value Added in region $)_{\text {it }}$ & Eurostat & Region-Time \\
\hline Demand & $\begin{array}{c}\text { Market } \\
\text { Potential }\end{array}$ & $\begin{array}{l}\text { Log of the sum of value added in } \\
\text { all regions } r \neq i \text { weighted by the } \\
\text { inverse euclidean distance between } \\
\text { the major cities in } r \text { and } i\end{array}$ & Eurostat & Region-Time \\
\hline \multirow{2}{*}{$\begin{array}{l}\text { Agglomeration } \\
\text { Economies }\end{array}$} & Overall agglomeration & $\begin{array}{l}\text { Log (cumulative number of } \\
\text { establishments })_{\mathrm{ijt}}\end{array}$ & Elios & $\begin{array}{l}\text { Region-Sector- } \\
\text { Time }\end{array}$ \\
\hline & $\begin{array}{l}\text { Foreign-firms } \\
\text { agglomeration }\end{array}$ & $\begin{array}{l}\text { Log (cumulative number of } \\
\text { foreign-owned })_{\mathrm{ijt}}\end{array}$ & Elios & $\begin{array}{l}\text { Region-Sector- } \\
\text { Time }\end{array}$ \\
\hline \multirow{2}{*}{$\begin{array}{l}\text { Local labor } \\
\text { market }\end{array}$} & Wages & $\begin{array}{c}\text { Log (labor cost } \text { itt }_{\text {la }} / \text { number of } \\
\text { employees }_{\text {it }} \text { ) }\end{array}$ & Eurostat & Region-Time \\
\hline & Unemployment Rate & Log $(\text { Unemployment rate })_{\text {it }}$ & Eurostat & Region-Time \\
\hline Technology & R\&D intensity & Log (R\&D95i / VA95i) & Eurostat & Region \\
\hline $\begin{array}{l}\text { Regional } \\
\text { policy }\end{array}$ & $\begin{array}{c}\text { Transport } \\
\text { Infrastructure }\end{array}$ & $\begin{array}{l}\text { Index of transport infrastructure } \\
\text { stock in region I at } 1995\end{array}$ & $\begin{array}{l}\text { Confidustria } \\
\text {-Ecoter }\end{array}$ & Region \\
\hline Human capital & $\begin{array}{l}\text { Secondary schooling } \\
\text { enrolment }\end{array}$ & $\begin{array}{c}\text { Log (Students enrolled in sec. } \\
\text { school at } 1995 \text { / Total pop. aged } \\
10-19)\end{array}$ & Eurostat & Region \\
\hline Specialization & $\begin{array}{l}\text { Normalized Balassa } \\
\text { Index }\end{array}$ & $\begin{array}{l}\qquad\left(\mathrm{X}_{\mathrm{ijt}} / \mathrm{X}_{\mathrm{jt}}\right) /\left(\mathrm{X}_{\mathrm{it}} / \mathrm{X}_{\mathrm{t}}\right) \\
\text { with } \mathrm{X}=\text { number of firms }\end{array}$ & Elios & $\begin{array}{l}\text { Region-Sector- } \\
\text { Time }\end{array}$ \\
\hline
\end{tabular}


Table A.2. Descriptive statistics, regional variables

\begin{tabular}{lccccc}
\hline Variable & Mean & Standard Dev. & Min & Median & Max \\
\hline Market size & 11.15 & 0.76 & 9.58 & 11.10 & 12.95 \\
Market potential & 13.46 & 0.34 & 12.61 & 13.56 & 14.22 \\
Agglomeration (overall) & 2.97 & 1.56 & 0.00 & 3.14 & 7.74 \\
Agglomeration (foreign) & 1.84 & 1.33 & 0.00 & 1.79 & 5.97 \\
Wage & 2.70 & 0.35 & 1.58 & 2.73 & 3.49 \\
Unemployment & 2.29 & 0.51 & 0.83 & 2.26 & 3.49 \\
R\&D intensity & 0.34 & 0.63 & -0.87 & 0.41 & 2.18 \\
Transport infra & 2.13 & 3.50 & 0.25 & 1.11 & 21.43 \\
Schooling rate & 4.43 & 0.21 & 4.05 & 4.40 & 5.14 \\
Specialization & -0.10 & 0.35 & -1.00 & -0.07 & 0.94 \\
\hline
\end{tabular}


Figure 1 - FDI inflows in the European Union as a \% of world flows, 1991-1999

European Union

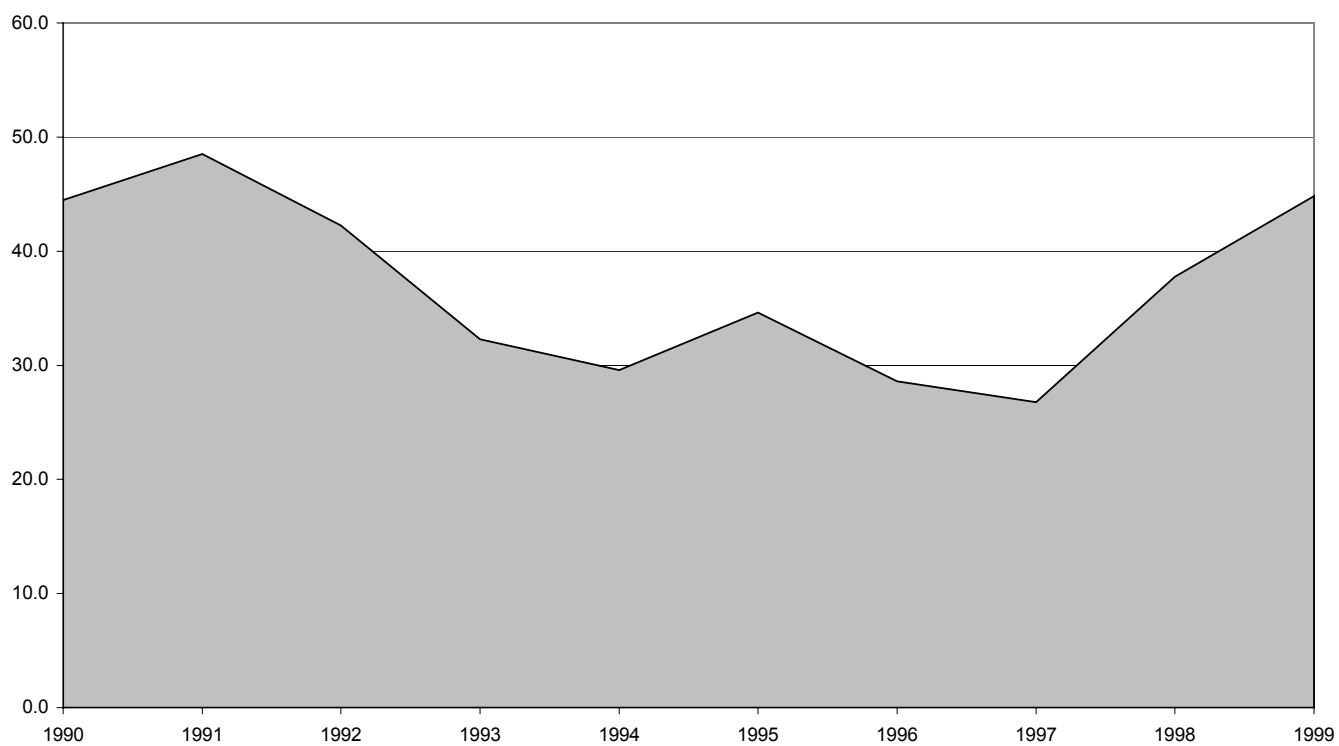

Source: Elaborations on UNCTAD data

Figure 2 - FDI inflows as a \% of gross fixed capital formation (GFCF) in the European Union and in 5 EU countries, 1991-1999

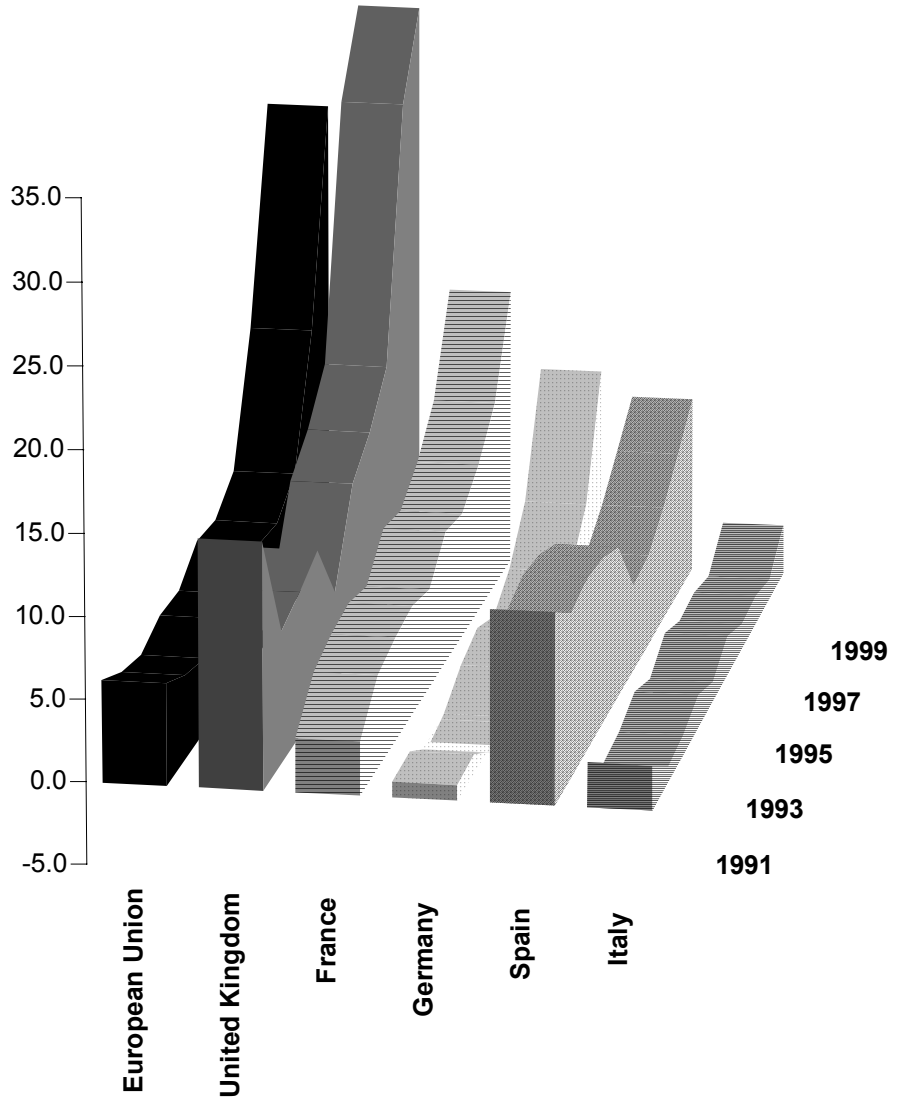

Source: Elaborations on UNCTAD data 
Figure 3 - Number of foreign subsidiaries established in 52 NUTS 1 regions in 5 EU countries, 1991-1999

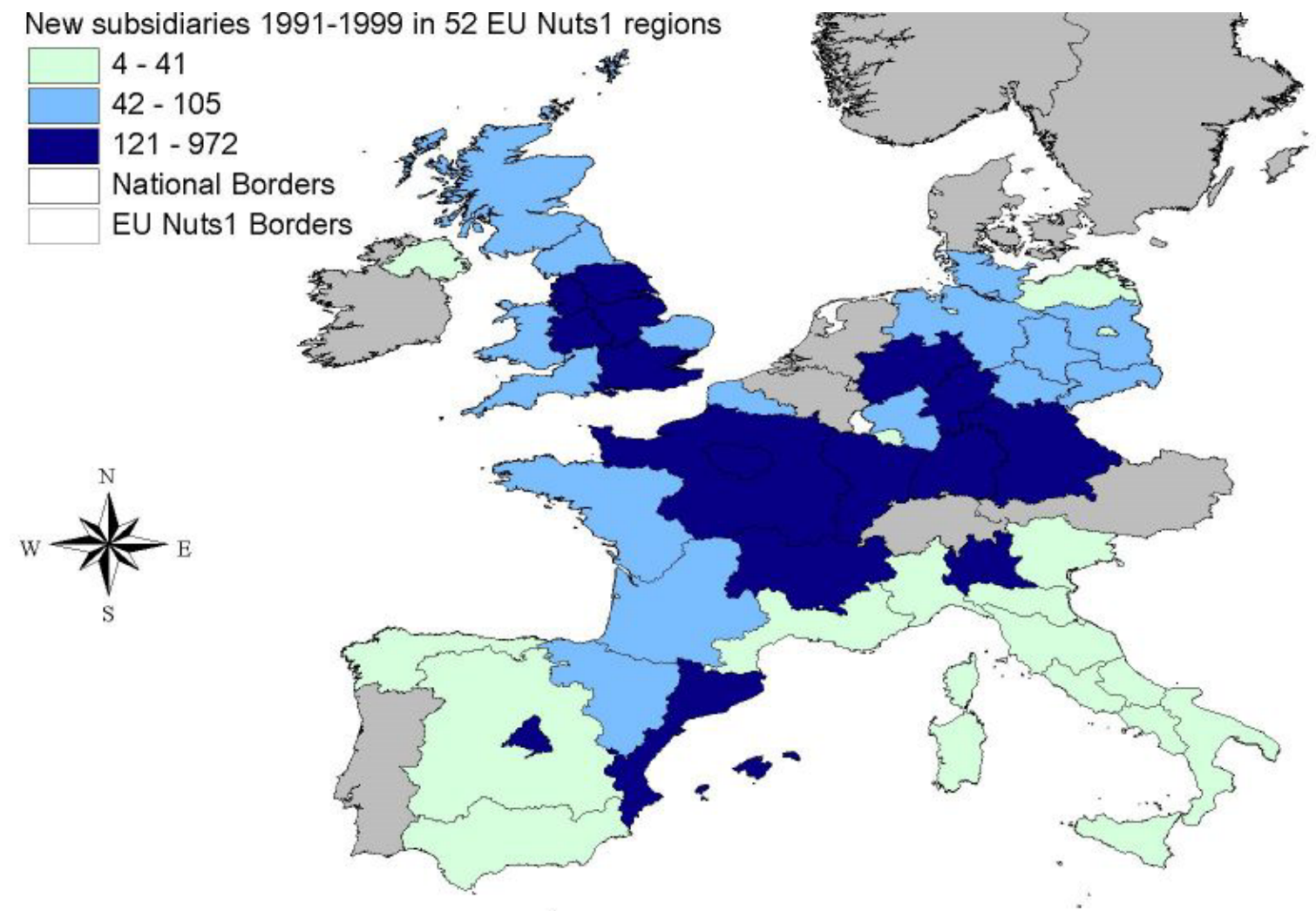

Source: Elaborations on Elios dataset (University of Urbino) 


\section{Appendix 2: Estimation method and simulation technique}

\section{The econometric model}

As our dependent variable $y_{i t}$ is a count (the number of FDI in each group, i.e. region, 2digit sector and period) we use a negative binomial regression model.

In particular, we used the random effect panel data model developed by Hausman, Hall, and Griliches $(1984)^{10}$. As it is common in random effect panel data techniques, the development of the likelihood rests on two step. First, a reasonable distribution of the set of observations belonging to a given individual $i$ conditional on the unobserved effect $\varepsilon_{i}$ is assumed. Second, by supposing a tractable distribution for the effect $\varepsilon_{i}$, the unconditional distribution of the set of observations belonging to a given individual $i$ is found.

Let $y_{i t}$ be the count for the $t^{\text {th }}$ observation in the $i^{\text {th }}$ group. Assume that:

(1) $y_{i t} \mid \gamma_{i t} \sim \operatorname{Po}\left(\gamma_{i t}\right)$

$$
\begin{aligned}
\gamma_{i t}=\exp \left(x_{i t}^{\prime} \beta+\varepsilon_{i}\right) & =\exp \left(x_{i t}^{\prime} \beta\right) \exp \left(\varepsilon_{i}\right)=\mu_{i t} v_{i} \\
\text { (3) } \quad v_{i} & \sim \Gamma\left(\delta_{i}, \frac{1}{\delta_{i}}\right)
\end{aligned}
$$

so that

(4) $\quad \gamma_{i t} \mid \delta_{i} \sim \Gamma\left(\mu_{i t}, \frac{1}{\delta_{i}}\right)$

where $\frac{1}{\delta_{i}}$ is the dispersion parameter. Then the following density (corresponding to a negative binomial type II) appears:

$$
\operatorname{Pr}\left(Y_{i t}=y_{i t} \mid \mathbf{x}_{i t}, \delta_{i}\right)=\frac{\Gamma\left(\mu_{i t}+y_{i t}\right)}{\Gamma\left(\mu_{i t}\right) \Gamma\left(y_{i t}+1\right)}\left(\frac{1}{1+\delta_{i}}\right)^{\mu_{i t}}\left(\frac{\delta_{i}}{1+\delta_{i}}\right)^{y_{i t}}
$$

and the joint probability of counts for the $i^{\text {th }}$ group (conditional on unobservable $\delta_{i}$ ) is:

$$
\operatorname{Pr}\left(Y_{i 1}=y_{i 1}, \ldots, Y_{i T}=y_{i T} \mid \mathbf{X}_{i}, \delta_{i}\right)=\prod_{t=1}^{T}\left[\frac{\Gamma\left(\mu_{i t}+y_{i t}\right)}{\Gamma\left(\mu_{i t}\right) \Gamma\left(y_{i t}+1\right)}\left(\frac{1}{1+\delta_{i}}\right)^{\mu_{i t}}\left(\frac{\delta_{i}}{1+\delta_{i}}\right)^{y_{i t}}\right]
$$

where $\mathbf{X}_{i}=\left[\begin{array}{llll}\mathbf{x}_{i 1} & \mathbf{x}_{i 2} \ldots \mathbf{x}_{i T}\end{array}\right]$

\footnotetext{
${ }^{10}$ For the development of the log-likelihood, see Cameron and Trivedi (1998), p. 100-2 and 287-8.
} 
If $\delta_{i}$ is allowed to differ across individuals, and in particular:

$$
\text { (7) } \frac{1}{1+\delta_{i}} \sim \operatorname{Beta}(r, s)
$$

then the unconditional distribution of counts for the $i^{\text {th }}$ group (unconditional on unobservable $\left.\delta_{i}\right)$ is:

$$
\begin{aligned}
& \operatorname{Pr}\left(Y_{i 1}=y_{i 1}, \ldots, Y_{i T}=y_{i T} \mid X_{i}\right)= \\
= & \int \prod_{t=1}^{T}\left[\frac{\Gamma\left(\mu_{i t}+y_{i t}\right)}{\Gamma\left(\mu_{i t}\right) \Gamma\left(y_{i t}+1\right)}\left(\frac{1}{1+\delta_{i}}\right)^{\mu_{i t}}\left(\frac{\delta_{i}}{1+\delta_{i}}\right)^{y_{i t}}\right] f\left(\delta_{i}\right) d \delta_{i}= \\
= & \frac{\Gamma(r+s) \Gamma\left(r+\sum_{t=1}^{T} \mu_{i t}\right) \Gamma\left(s+\sum_{t=1}^{T} y_{i t}\right)}{\Gamma(r) \Gamma(s) \Gamma\left(r+s+\sum_{t=1}^{T} \mu_{i t}+\sum_{t=1}^{T} y_{i t}\right)} \times \\
& \prod_{t=1}^{T} \frac{\Gamma\left(\mu_{i t}+y_{i t}\right)}{\Gamma\left(\mu_{i t}\right) \Gamma\left(y_{i t}+1\right)}
\end{aligned}
$$

This density is the basis of maximum likelihood estimation of $\boldsymbol{\beta}, r, s$. Estimation of the model is performed with the Stata software, release 8.2.

\section{Simulations}

Simulations have been run in the following way. First, we predicted the value of the dependent variable for each region of interest (North-West, Lombardy, North-East, Centre, and South) given the actual value of the regressors observed in the last period (1997-99). As some regressors are industry specific, we computed 20 predicted values, one for each two digit industry. Then we repeated the prediction setting each regressor at its mean value in the EU countries other than Italy in the same period. Finally, we computed the average (by sector) of the prediction based on both modified and original regressors and we computed the percentage change due to the change of the regressor. In the case of Italy, we followed the same procedure but the prediction value in the first stage is computed at the average value of the regressors in all Italian regions. 
Table 1. - Regression results: Do Italian regions attract less FDI than their potential?

\begin{tabular}{|c|c|c|c|c|c|c|c|c|}
\hline & (1) & (2) & (3) & (4) & (5) & (6) & (7) & (8) \\
\hline Market size & $\begin{array}{c}0.213 \\
{[0.000]}\end{array}$ & $\begin{array}{c}0.240 \\
{[0.000]}\end{array}$ & $\begin{array}{c}0.219 \\
{[0.000]}\end{array}$ & $\begin{array}{c}0.217 \\
{[0.000]}\end{array}$ & $\begin{array}{c}0.241 \\
{[0.000]}\end{array}$ & $\begin{array}{c}0.221 \\
{[0.000]}\end{array}$ & $\begin{array}{c}0.222 \\
{[0.000]}\end{array}$ & $\begin{array}{c}0.220 \\
{[0.000]}\end{array}$ \\
\hline Market potential & $\begin{array}{c}0.365 \\
{[0.000]}\end{array}$ & $\begin{array}{c}0.357 \\
{[0.000]}\end{array}$ & $\begin{array}{c}0.373 \\
{[0.000]}\end{array}$ & $\begin{array}{c}0.377 \\
{[0.000]}\end{array}$ & $\begin{array}{c}0.351 \\
{[0.000]}\end{array}$ & $\begin{array}{c}0.373 \\
{[0.000]}\end{array}$ & $\begin{array}{c}0.380 \\
{[0.000]}\end{array}$ & $\begin{array}{c}0.366 \\
{[0.000]}\end{array}$ \\
\hline $\begin{array}{l}\text { Agglomeration } \\
\text { (overall) }\end{array}$ & $\begin{array}{c}0.179 \\
{[0.000]}\end{array}$ & $\begin{array}{c}0.175 \\
{[0.000]}\end{array}$ & $\begin{array}{c}0.172 \\
{[0.000]}\end{array}$ & $\begin{array}{c}0.170 \\
{[0.000]}\end{array}$ & $\begin{array}{c}0.174 \\
{[0.000]}\end{array}$ & $\begin{array}{c}0.176 \\
{[0.000]}\end{array}$ & $\begin{array}{c}0.174 \\
{[0.000]}\end{array}$ & $\begin{array}{c}0.171 \\
{[0.000]}\end{array}$ \\
\hline $\begin{array}{l}\text { Agglomeration } \\
\text { (foreign) }\end{array}$ & $\begin{array}{c}0.652 \\
{[0.000]}\end{array}$ & $\begin{array}{c}0.592 \\
{[0.000]}\end{array}$ & $\begin{array}{c}0.634 \\
{[0.000]}\end{array}$ & $\begin{array}{c}0.636 \\
{[0.000]}\end{array}$ & $\begin{array}{c}0.590 \\
{[0.000]}\end{array}$ & $\begin{array}{c}0.629 \\
{[0.000]}\end{array}$ & $\begin{array}{c}0.626 \\
{[0.000]}\end{array}$ & $\begin{array}{c}0.631 \\
{[0.000]}\end{array}$ \\
\hline Wage & $\begin{array}{l}-0.780 \\
{[0.000]}\end{array}$ & $\begin{array}{c}-0.754 \\
{[0.000]}\end{array}$ & $\begin{array}{l}-0.759 \\
{[0.000]}\end{array}$ & $\begin{array}{l}-0.751 \\
{[0.000]}\end{array}$ & $\begin{array}{l}-0.753 \\
{[0.000]}\end{array}$ & $\begin{array}{c}-0.762 \\
{[0.000]}\end{array}$ & $\begin{array}{c}-0.766 \\
{[0.000]}\end{array}$ & $\begin{array}{l}-0.757 \\
{[0.000]}\end{array}$ \\
\hline Unemployment & $\begin{array}{c}0.033 \\
{[0.476]}\end{array}$ & $\begin{array}{l}-0.048 \\
{[0.338]}\end{array}$ & $\begin{array}{c}-0.077 \\
{[0.120]}\end{array}$ & $\begin{array}{l}-0.069 \\
{[0.166]}\end{array}$ & $\begin{array}{l}-0.047 \\
{[0.344]}\end{array}$ & $\begin{array}{c}-0.084 \\
{[0.090]}\end{array}$ & $\begin{array}{c}-0.073 \\
{[0.138]}\end{array}$ & $\begin{array}{l}-0.072 \\
{[0.145]}\end{array}$ \\
\hline R\&D intensity & $\begin{array}{c}0.220 \\
{[0.000]}\end{array}$ & $\begin{array}{c}0.124 \\
{[0.006]}\end{array}$ & $\begin{array}{c}0.118 \\
{[0.008]}\end{array}$ & $\begin{array}{c}0.126 \\
{[0.005]}\end{array}$ & $\begin{array}{c}0.123 \\
{[0.006]}\end{array}$ & $\begin{array}{c}0.110 \\
{[0.015]}\end{array}$ & $\begin{array}{c}0.120 \\
{[0.007]}\end{array}$ & $\begin{array}{c}0.119 \\
{[0.008]}\end{array}$ \\
\hline Transport infrastructure & $\begin{array}{c}0.036 \\
{[0.034]}\end{array}$ & $\begin{array}{c}0.056 \\
{[0.001]}\end{array}$ & $\begin{array}{c}0.051 \\
{[0.003]}\end{array}$ & $\begin{array}{c}0.050 \\
{[0.003]}\end{array}$ & $\begin{array}{c}0.056 \\
{[0.001]}\end{array}$ & $\begin{array}{c}0.052 \\
{[0.002]}\end{array}$ & $\begin{array}{c}0.052 \\
{[0.002]}\end{array}$ & $\begin{array}{c}0.051 \\
{[0.002]}\end{array}$ \\
\hline Schooling rate & $\begin{array}{c}1.114 \\
{[0.000]}\end{array}$ & $\begin{array}{c}0.873 \\
{[0.000]}\end{array}$ & $\begin{array}{c}0.753 \\
{[0.000]}\end{array}$ & $\begin{array}{c}0.753 \\
{[0.000]}\end{array}$ & $\begin{array}{c}0.881 \\
{[0.000]}\end{array}$ & $\begin{array}{c}0.754 \\
{[0.000]}\end{array}$ & $\begin{array}{c}0.777 \\
{[0.000]}\end{array}$ & $\begin{array}{c}0.767 \\
{[0.000]}\end{array}$ \\
\hline Specialization & $\begin{array}{c}0.239 \\
{[0.014]}\end{array}$ & $\begin{array}{c}0.361 \\
{[0.000]}\end{array}$ & $\begin{array}{c}0.301 \\
{[0.003]}\end{array}$ & $\begin{array}{c}0.303 \\
{[0.003]}\end{array}$ & $\begin{array}{c}0.364 \\
{[0.000]}\end{array}$ & $\begin{array}{c}0.302 \\
{[0.003]}\end{array}$ & $\begin{array}{c}0.311 \\
{[0.002]}\end{array}$ & $\begin{array}{c}0.307 \\
{[0.002]}\end{array}$ \\
\hline Italy & $\begin{array}{l}--- \\
---\end{array}$ & --- & $\begin{array}{l}-0.505 \\
{[0.000]}\end{array}$ & $\begin{array}{l}-0.457 \\
{[0.000]}\end{array}$ & $\begin{array}{l}-0.752 \\
{[0.000]}\end{array}$ & $\begin{array}{l}-0.482 \\
{[0.000]}\end{array}$ & $\begin{array}{l}-0.421 \\
{[0.000]}\end{array}$ & $\begin{array}{l}-0.487 \\
{[0.000]}\end{array}$ \\
\hline $\begin{array}{l}\text { North West } \\
\text { (excl. Lombardy) }\end{array}$ & $\begin{array}{l}--- \\
---\end{array}$ & $\begin{array}{l}-0.801 \\
{[0.000]}\end{array}$ & --- & $\begin{array}{l}-0.350 \\
{[0.121]}\end{array}$ & --- & $\begin{array}{l}--- \\
---\end{array}$ & --- & $\begin{array}{l}-- \\
---\end{array}$ \\
\hline Lombardy & --- & $\begin{array}{l}-0.109 \\
{[0.355]}\end{array}$ & --- & --- & $\begin{array}{c}0.646 \\
{[0.000]}\end{array}$ & $\begin{array}{l}--- \\
---\end{array}$ & --- & --- \\
\hline North East & --- & $\begin{array}{l}-0.737 \\
{[0.001]}\end{array}$ & --- & --- & --- & $\begin{array}{l}-0.278 \\
{[0.226]}\end{array}$ & --- & --- \\
\hline Centre & --- & $\begin{array}{l}-0.783 \\
{[0.000]}\end{array}$ & --- & --- & --- & --- & $\begin{array}{l}-0.351 \\
{[0.036]}\end{array}$ & --- \\
\hline South & --- & $\begin{array}{l}-0.663 \\
{[0.001]}\end{array}$ & --- & --- & --- & --- & --- & $\begin{array}{l}-0.121 \\
{[0.560]}\end{array}$ \\
\hline Constant & $\begin{array}{l}-11.210 \\
{[0.000]}\end{array}$ & $\begin{array}{l}-9.882 \\
{[0.000]}\end{array}$ & $\begin{array}{l}-9.366 \\
{[0.000]}\end{array}$ & $\begin{array}{l}-9.433 \\
{[0.000]}\end{array}$ & $\begin{array}{l}-9.847 \\
{[0.000]}\end{array}$ & $\begin{array}{l}-9.371 \\
{[0.000]}\end{array}$ & $\begin{array}{l}-9.583 \\
{[0.000]}\end{array}$ & $\begin{array}{l}-9.348 \\
{[0.000]}\end{array}$ \\
\hline $\operatorname{Ln} r$ & $\begin{array}{c}6.169 \\
{[0.000]}\end{array}$ & $\begin{array}{c}5.758 \\
{[0.000]}\end{array}$ & $\begin{array}{c}5.751 \\
{[0.000]}\end{array}$ & $\begin{array}{c}5.777 \\
{[0.000]}\end{array}$ & $\begin{array}{c}5.754 \\
{[0.000]}\end{array}$ & $\begin{array}{c}5.752 \\
{[0.000]}\end{array}$ & $\begin{array}{c}5.792 \\
{[0.000]}\end{array}$ & $\begin{array}{c}5.753 \\
{[0.000]}\end{array}$ \\
\hline Ln s & $\begin{array}{c}5.061 \\
{[0.000]}\end{array}$ & $\begin{array}{c}4.515 \\
{[0.000]}\end{array}$ & $\begin{array}{c}4.547 \\
{[0.000]}\end{array}$ & $\begin{array}{c}4.568 \\
{[0.000]}\end{array}$ & $\begin{array}{c}4.509 \\
{[0.000]}\end{array}$ & $\begin{array}{c}4.548 \\
{[0.000]}\end{array}$ & $\begin{array}{c}4.585 \\
{[0.000]}\end{array}$ & $\begin{array}{c}4.545 \\
{[0.000]}\end{array}$ \\
\hline Log-likelihood & -3682.1 & -3653.1 & -3663.3 & -3662.0 & -3653.3 & -3662.5 & -3661.0 & -3663.1 \\
\hline N. obs. & 3120 & 3120 & 3120 & 3120 & 3120 & 3120 & 3120 & 3120 \\
\hline
\end{tabular}

Notes: The dependent variable is the number of FDI in each sector/period/region observation. Parameters are estimated with a negative binomial random effect panel method (see appendix 2). All regressions include a full set of 2-digit industry dummies and a dummy for three German regions outliers for infrastructures (not shown). $\mathrm{r}$ and $\mathrm{s}$ are parameters of the negative binomial conditional distribution. P-values in square brackets. 
Table 2. - Data on National Institutions and Policies: International Comparison

\begin{tabular}{lccc}
\hline & $\mathbf{1 9 9 1}$ & $\mathbf{1 9 9 4}$ & $\mathbf{1 9 9 7}$ \\
\hline & \multicolumn{3}{c}{$\boldsymbol{T A X} \boldsymbol{W E D G E} \boldsymbol{O N} \boldsymbol{~} \boldsymbol{L A B O R}$} \\
\hline France & 42.3 & 43.7 & 44.2 \\
Germany & 37.2 & 39 & 41.2 \\
Italy & 35.6 & 39.6 & 45.4 \\
Spain & 31.8 & 34.6 & 32.7 \\
United Kingdom & 23.5 & 25.3 & 24.2 \\
\hline
\end{tabular}

LABOUR REGULATIONS

\begin{tabular}{lccc}
\hline France & 4.3 & 4.2 & 2.8 \\
Germany & 4.3 & 4.2 & 2.4 \\
Italy & 2.7 & 2.8 & 2.1 \\
Spain & 2.2 & 2.6 & 3.3 \\
United Kingdom & 7.7 & 7.5 & 8.3 \\
\hline \multicolumn{3}{c}{ CORPORATE TAX RATE } \\
\hline France & 27.6 & 27.0 & 34.6 \\
Germany & 51.8 & 46.1 & 49.2 \\
Italy & 39.4 & 43.8 & 41.3 \\
Spain & 31.0 & 27.5 & 27.5 \\
United Kingdom & 28.4 & 28.4 & 26.6 \\
\hline & \multicolumn{3}{c}{ BUREAUCRACY } \\
\hline France & 3.4 & 3.4 & 2.9 \\
Germany & 3.8 & 3.8 & 2.9 \\
Italy & 1.8 & 1.8 & 1.3 \\
Spain & 3.3 & 3.3 & 3.8 \\
United Kingdom & 4.9 & 4.9 & 5.1 \\
\hline
\end{tabular}

LEGAL SYSTEM AND IPR

\begin{tabular}{llll}
\hline France & 7.7 & 7.5 & 8.1 \\
Germany & 8.3 & 9.1 & 9.1 \\
Italy & 7.7 & 6.5 & 7.7 \\
Spain & 7.2 & 7.5 & 7.5 \\
United Kingdom & 7.7 & 8.8 & 9.2
\end{tabular}

Variable definitions:

- TAX WEDGE ON LABOR: Average Effective Tax Wedge, share of labour cost due to taxation (Source: OECD database on the tax/benefits positions of employees).

- EFFECTIVE AVERAGE CORPORATE TAX RATE: (Source: IFS)

- LABOUR REGULATIONS: Labour regulations (hiring and firing practices, minimum wages,..) do not hinder business activity (Source: IMD; $0=$ more restrictive; $10=$ less restrictive).

- BUREAUCRACY: Bureaucracy does not hinder business activity (Source: IMD; 0=less efficient; $10=$ more efficient).

- LEGAL SYSTEM AND INTELLECTUAL PROPERTY RIGHT: Patents and copyright protection is adequately enforced in your country (Source: Frazer Institute; $0=$ less effective; 10=more effective). 
Table 3. - Regression results: the effects of national institutions and policies.

\begin{tabular}{|c|c|c|c|c|c|c|c|}
\hline & (9) & $(10)$ & (11) & (12) & (13) & (14) & (15) \\
\hline Market size & $\begin{array}{c}0.430 \\
{[0.000]}\end{array}$ & $\begin{array}{c}0.163 \\
{[0.001]}\end{array}$ & $\begin{array}{c}0.245 \\
{[0.000]}\end{array}$ & $\begin{array}{c}0.372 \\
{[0.000]}\end{array}$ & $\begin{array}{c}0.326 \\
{[0.000]}\end{array}$ & $\begin{array}{c}0.352 \\
{[0.000]}\end{array}$ & $\begin{array}{c}1.139 \\
{[0.000]}\end{array}$ \\
\hline Market potential & $\begin{array}{c}0.643 \\
{[0.000]}\end{array}$ & $\begin{array}{c}0.322 \\
{[0.002]}\end{array}$ & $\begin{array}{c}0.340 \\
{[0.001]}\end{array}$ & $\begin{array}{c}0.546 \\
{[0.000]}\end{array}$ & $\begin{array}{c}0.433 \\
{[0.000]}\end{array}$ & $\begin{array}{c}0.507 \\
{[0.000]}\end{array}$ & $\begin{array}{c}1.272 \\
{[0.000]}\end{array}$ \\
\hline $\begin{array}{l}\text { Agglomeration } \\
\text { (overall) }\end{array}$ & $\begin{array}{c}0.066 \\
{[0.122]}\end{array}$ & $\begin{array}{c}0.215 \\
{[0.000]}\end{array}$ & $\begin{array}{c}0.156 \\
{[0.000]}\end{array}$ & $\begin{array}{c}0.077 \\
{[0.052]}\end{array}$ & $\begin{array}{c}0.080 \\
{[0.062]}\end{array}$ & $\begin{array}{c}0.105 \\
{[0.058]}\end{array}$ & $\begin{array}{l}--- \\
---\end{array}$ \\
\hline $\begin{array}{l}\text { Agglomeration } \\
\text { (foreign) }\end{array}$ & $\begin{array}{c}0.583 \\
{[0.000]}\end{array}$ & $\begin{array}{c}0.646 \\
{[0.000]}\end{array}$ & $\begin{array}{c}0.657 \\
{[0.000]}\end{array}$ & $\begin{array}{c}0.617 \\
{[0.000]}\end{array}$ & $\begin{array}{c}0.644 \\
{[0.000]}\end{array}$ & $\begin{array}{c}0.632 \\
{[0.000]}\end{array}$ & --- \\
\hline Wage & $\begin{array}{c}-0.742 \\
{[0.000]}\end{array}$ & $\begin{array}{c}-0.768 \\
{[0.000]}\end{array}$ & $\begin{array}{c}-1.012 \\
{[0.000]}\end{array}$ & $\begin{array}{c}-0.739 \\
{[0.000]}\end{array}$ & $\begin{array}{c}-0.757 \\
{[0.000]}\end{array}$ & $\begin{array}{c}-0.931 \\
{[0.000]}\end{array}$ & $\begin{array}{c}-0.802 \\
{[0.000]}\end{array}$ \\
\hline Unemployment & $\begin{array}{c}0.032 \\
{[0.569]}\end{array}$ & $\begin{array}{c}-0.068 \\
{[0.170]}\end{array}$ & $\begin{array}{c}-0.142 \\
{[0.005]}\end{array}$ & $\begin{array}{c}0.035 \\
{[0.524]}\end{array}$ & $\begin{array}{c}-0.001 \\
{[0.992]}\end{array}$ & $\begin{array}{c}-0.019 \\
{[0.764]}\end{array}$ & $\begin{array}{c}0.114 \\
{[0.081]}\end{array}$ \\
\hline$R \& D$ intensity & $\begin{array}{c}0.103 \\
{[0.019]}\end{array}$ & $\begin{array}{c}0.112 \\
{[0.012]}\end{array}$ & $\begin{array}{c}0.086 \\
{[0.054]}\end{array}$ & $\begin{array}{c}0.108 \\
{[0.014]}\end{array}$ & $\begin{array}{c}0.110 \\
{[0.013]}\end{array}$ & $\begin{array}{c}0.082 \\
{[0.067]}\end{array}$ & $\begin{array}{c}0.051 \\
{[0.318]}\end{array}$ \\
\hline Transport infra & $\begin{array}{c}0.032 \\
{[0.064]}\end{array}$ & $\begin{array}{c}0.056 \\
{[0.001]}\end{array}$ & $\begin{array}{c}0.060 \\
{[0.000]}\end{array}$ & $\begin{array}{c}0.033 \\
{[0.058]}\end{array}$ & $\begin{array}{c}0.035 \\
{[0.043]}\end{array}$ & $\begin{array}{c}0.044 \\
{[0.014]}\end{array}$ & $\begin{array}{c}0.040 \\
{[0.053]}\end{array}$ \\
\hline Schooling rate & $\begin{array}{c}0.424 \\
{[0.019]}\end{array}$ & $\begin{array}{c}0.623 \\
{[0.000]}\end{array}$ & $\begin{array}{c}0.512 \\
{[0.002]}\end{array}$ & $\begin{array}{c}0.511 \\
{[0.002]}\end{array}$ & $\begin{array}{c}0.661 \\
{[0.000]}\end{array}$ & $\begin{array}{c}0.225 \\
{[0.260]}\end{array}$ & $\begin{array}{c}0.463 \\
{[0.032]}\end{array}$ \\
\hline Specialization & $\begin{array}{c}0.597 \\
{[0.000]}\end{array}$ & $\begin{array}{c}0.195 \\
{[0.103]}\end{array}$ & $\begin{array}{c}0.300 \\
{[0.002]}\end{array}$ & $\begin{array}{c}0.526 \\
{[0.000]}\end{array}$ & $\begin{array}{c}0.478 \\
{[0.000]}\end{array}$ & $\begin{array}{c}0.445 \\
{[0.002]}\end{array}$ & $\begin{array}{c}1.641 \\
{[0.000]}\end{array}$ \\
\hline Italy & $\begin{array}{c}-0.537 \\
{[0.000]}\end{array}$ & $\begin{array}{c}-0.537 \\
{[0.000]}\end{array}$ & $\begin{array}{l}-0.442 \\
{[0.000]}\end{array}$ & $\begin{array}{c}-0.016 \\
{[0.908]}\end{array}$ & $\begin{array}{c}-0.439 \\
{[0.000]}\end{array}$ & $\begin{array}{c}0.074 \\
{[0.816]}\end{array}$ & $\begin{array}{l}-0.323 \\
{[0.314]}\end{array}$ \\
\hline Tax wedge on labour & $\begin{array}{c}-0.740 \\
{[0.000]}\end{array}$ & $\begin{array}{l}--- \\
---\end{array}$ & $\begin{array}{l}--- \\
---\end{array}$ & --- & --- & $\begin{array}{c}-0.021 \\
{[0.944]}\end{array}$ & $\begin{array}{l}-1.755 \\
{[0.000]}\end{array}$ \\
\hline Corporate tax & $\begin{array}{l}--- \\
---\end{array}$ & $\begin{array}{c}0.222 \\
{[0.105]}\end{array}$ & $\begin{array}{l}--- \\
---\end{array}$ & $\begin{array}{l}--- \\
---\end{array}$ & $\begin{array}{l}--- \\
---\end{array}$ & $\begin{array}{c}0.119 \\
{[0.477]}\end{array}$ & $\begin{array}{l}-0.870 \\
{[0.000]}\end{array}$ \\
\hline Legal system & $\begin{array}{l}--- \\
---\end{array}$ & $\begin{array}{l}--- \\
---\end{array}$ & $\begin{array}{c}1.276 \\
{[0.000]}\end{array}$ & $\begin{array}{l}--- \\
---\end{array}$ & $\begin{array}{l}--- \\
---\end{array}$ & $\begin{array}{c}0.994 \\
{[0.001]}\end{array}$ & $\begin{array}{c}1.061 \\
{[0.001]}\end{array}$ \\
\hline Bureaucracy & $\begin{array}{l}--- \\
---\end{array}$ & --- & --- & $\begin{array}{c}0.709 \\
{[0.000]}\end{array}$ & $\begin{array}{l}--- \\
---\end{array}$ & $\begin{array}{c}0.822 \\
{[0.088]}\end{array}$ & $\begin{array}{c}0.607 \\
{[0.212]}\end{array}$ \\
\hline Hiring/Firing costs & $\begin{array}{l}--- \\
---\end{array}$ & --- & $\begin{array}{l}--- \\
---\end{array}$ & $\begin{array}{l}--- \\
---\end{array}$ & $\begin{array}{c}0.244 \\
{[0.000]}\end{array}$ & $\begin{array}{c}-0.092 \\
{[0.618]}\end{array}$ & $\begin{array}{c}-0.382 \\
{[0.047]}\end{array}$ \\
\hline constant & $\begin{array}{l}-11.150 \\
{[0.000]}\end{array}$ & $\begin{array}{c}-8.412 \\
{[0.000]}\end{array}$ & $\begin{array}{c}-9.965 \\
{[0.000]}\end{array}$ & $\begin{array}{c}-13.216 \\
{[0.000]}\end{array}$ & $\begin{array}{l}-11.186 \\
{[0.000]}\end{array}$ & $\begin{array}{l}-13.105 \\
{[0.000]}\end{array}$ & $\begin{array}{l}-22.234 \\
{[0.000]}\end{array}$ \\
\hline $\operatorname{Ln} \mathrm{r}$ & $\begin{array}{c}6.144 \\
{[0.000]}\end{array}$ & $\begin{array}{c}5.851 \\
{[0.000]}\end{array}$ & $\begin{array}{c}6.107 \\
{[0.000]}\end{array}$ & $\begin{array}{c}6.028 \\
{[0.000]}\end{array}$ & $\begin{array}{c}5.847 \\
{[0.000]}\end{array}$ & $\begin{array}{c}6.322 \\
{[0.000]}\end{array}$ & $\begin{array}{c}4.089 \\
{[0.000]}\end{array}$ \\
\hline Ln s & $\begin{array}{c}4.943 \\
{[0.000]}\end{array}$ & $\begin{array}{c}4.653 \\
{[0.000]}\end{array}$ & $\begin{array}{c}4.888 \\
{[0.000]}\end{array}$ & $\begin{array}{c}4.802 \\
{[0.000]}\end{array}$ & $\begin{array}{c}4.621 \\
{[0.000]}\end{array}$ & $\begin{array}{c}5.081 \\
{[0.000]}\end{array}$ & $\begin{array}{c}2.777 \\
{[0.000]}\end{array}$ \\
\hline Log-likelihood & -3655.2 & -3662.0 & -3652.9 & -3652.6 & -3657.2 & -3643.9 & -3740.0 \\
\hline N. obs. & 3120 & 3120 & 3120 & 3120 & 3120 & 3120 & 3120 \\
\hline
\end{tabular}

Notes: as in Table 1 
Table 4. - Regression results: asymmetric effects of national institutions and policies.

\begin{tabular}{|c|c|c|c|c|c|c|c|}
\hline Main Effect & Interaction with area dummy & $(1)$ & $(2)$ & (3) & (4) & $(5)$ & $(6)$ \\
\hline Lombardy & & $\begin{array}{c}0.393 \\
{[0.219]}\end{array}$ & $\begin{array}{c}-3.239 \\
\end{array}$ & $\begin{array}{c}8.573 \\
\end{array}$ & $\begin{array}{c}-3.338 \\
\end{array}$ & 1.272 & $\begin{array}{c}2.286 \\
{[0.044]}\end{array}$ \\
\hline North West & & -0.338 & 6.921 & 13.318 & -2.786 & $\begin{array}{l}0.0727 \\
-0.327\end{array}$ & -0.731 \\
\hline (excl. Lombardy) & & {$[0.371]$} & {$[0.388]$} & {$[0.482]$} & {$[0.595]$} & {$[0.729]$} & {$[0.725]$} \\
\hline \multirow[t]{2}{*}{ North East } & & -0.300 & -9.999 & 3.883 & -4.599 & 1.030 & 2.817 \\
\hline & & {$[0.425]$} & {$[0.205]$} & {$[0.833]$} & {$[0.405]$} & {$[0.213]$} & {$[0.123]$} \\
\hline \multirow[t]{2}{*}{ Centre } & & -0.336 & -2.542 & 6.041 & -3.186 & 0.425 & 1.217 \\
\hline & & {$[0.329]$} & {$[0.650]$} & {$[0.649]$} & {$[0.403]$} & {$[0.565]$} & [0.414] \\
\hline \multirow{2}{*}{ South } & & -0.302 & 12.728 & 42.054 & -10.563 & -0.246 & -0.404 \\
\hline & & {$[0.432]$} & {$[0.091]$} & {$[0.019]$} & {$[0.050]$} & {$[0.787]$} & {$[0.831]$} \\
\hline \multirow[t]{12}{*}{ Tax wedge on labour } & & -0.264 & -0.203 & -0.169 & -0.036 & -0.059 & -0.033 \\
\hline & & {$[0.390]$} & {$[0.529]$} & {$[0.587]$} & {$[0.912]$} & {$[0.862]$} & [0.923] \\
\hline & Lombardy & --- & 1.011 & --- & --- & --- & --- \\
\hline & & --- & {$[0.331]$} & --- & --- & --- & --- \\
\hline & North West & --- & -1.946 & --- & --- & --- & --- \\
\hline & (excl. Lombardy) & --- & {$[0.377]$} & --- & --- & --- & --- \\
\hline & North East & --- & 2.656 & --- & --- & --- & --- \\
\hline & & --- & {$[0.216]$} & --- & --- & --- & --- \\
\hline & Centre & --- & 0.626 & --- & --- & --- & --- \\
\hline & & --- & {$[0.685]$} & --- & --- & --- & --- \\
\hline & South & --- & -3.523 & --- & --- & --- & --- \\
\hline & & --- & {$[0.090]$} & --- & --- & --- & --- \\
\hline \multirow[t]{12}{*}{ Corporate tax } & & 0.033 & 0.015 & 0.157 & 0.173 & 0.007 & 0.012 \\
\hline & & {$[0.842]$} & {$[0.930]$} & {$[0.390]$} & {$[0.334]$} & {$[0.969]$} & [0.943] \\
\hline & Lombardy & --- & --- & -2.187 & --- & --- & --- \\
\hline & & --- & --- & {$[0.349]$} & --- & --- & --- \\
\hline & North West & --- & --- & -3.662 & --- & --- & --- \\
\hline & (excl. Lombardy) & --- & --- & {$[0.472]$} & --- & --- & --- \\
\hline & North East & --- & --- & -1.106 & --- & --- & --- \\
\hline & & --- & --- & {$[0.823]$} & --- & --- & --- \\
\hline & Centre & --- & --- & -1.701 & --- & --- & --- \\
\hline & & --- & --- & {$[0.633]$} & --- & --- & --- \\
\hline & South & --- & --- & -11.389 & --- & --- & --- \\
\hline & & --- & --- & {$[0.018]$} & --- & --- & --- \\
\hline \multirow[t]{12}{*}{ Legal system } & & 0.987 & 1.000 & 0.688 & 0.575 & 0.931 & 0.904 \\
\hline & & {$[0.001]$} & {$[0.001]$} & {$[0.053]$} & [0.111] & {$[0.003]$} & [0.004] \\
\hline & Lombardy & --- & --- & --- & 2.012 & --- & --- \\
\hline & & --- & --- & --- & {$[0.116]$} & --- & --- \\
\hline & North West & --- & --- & --- & 1.358 & --- & --- \\
\hline & (excl. Lombardy) & --- & --- & --- & [0.609] & --- & --- \\
\hline & North East & --- & --- & --- & 2.313 & --- & --- \\
\hline & & --- & --- & --- & {$[0.406]$} & --- & --- \\
\hline & Centre & --- & --- & --- & 1.573 & --- & --- \\
\hline & & --- & --- & --- & [0.417] & --- & --- \\
\hline & South & --- & --- & --- & 5.283 & --- & --- \\
\hline & & --- & --- & --- & {$[0.050]$} & --- & --- \\
\hline \multirow[t]{12}{*}{ Bureaucracy } & & 0.618 & 0.787 & 0.691 & 1.068 & 1.232 & 1.301 \\
\hline & & {$[0.199]$} & {$[0.183]$} & {$[0.154]$} & {$[0.039]$} & {$[0.057]$} & [0.046] \\
\hline & Lombardy & --- & --- & --- & --- & -1.056 & --- \\
\hline & & --- & --- & --- & --- & {$[0.102]$} & --- \\
\hline & North West & --- & --- & --- & --- & 0.707 & --- \\
\hline & (excl. Lombardy) & --- & --- & --- & --- & {$[0.620]$} & --- \\
\hline & North East & --- & --- & --- & --- & -1.988 & --- \\
\hline & & --- & --- & --- & --- & {$[0.116]$} & --- \\
\hline & Centre & --- & --- & --- & --- & -0.792 & --- \\
\hline & & --- & --- & --- & --- & {$[0.409]$} & --- \\
\hline & South & --- & --- & --- & --- & 0.668 & --- \\
\hline & & --- & --- & --- & --- & {$[0.605]$} & --- \\
\hline \multirow[t]{12}{*}{ Hiring/Firing costs } & & -0.027 & -0.089 & 0.001 & -0.112 & -0.233 & -0.253 \\
\hline & & {$[0.885]$} & {$[0.694]$} & {$[0.997]$} & {$[0.551]$} & {$[0.322]$} & {$[0.283]$} \\
\hline & Lombardy & --- & --- & --- & --- & --- & -1.615 \\
\hline & & --- & --- & --- & --- & --- & {$[0.085]$} \\
\hline & North West & --- & --- & --- & --- & --- & 0.858 \\
\hline & (excl. Lombardy) & --- & --- & --- & --- & --- & {$[0.676]$} \\
\hline & North East & --- & --- & --- & --- & --- & -2.944 \\
\hline & & --- & --- & --- & --- & --- & [0.109] \\
\hline & Centre & --- & --- & --- & --- & --- & -1.232 \\
\hline & & --- & --- & --- & --- & --- & {$[0.376]$} \\
\hline & South & --- & --- & --- & --- & --- & 0.580 \\
\hline & & --- & --- & --- & --- & --- & {$[0.751]$} \\
\hline Log-likelihood & & $\begin{array}{ll}-3631.8 \\
\end{array}$ & -3628.3 & -3628.3 & -3628.4 & $\begin{array}{l}-3628.8 \\
\end{array}$ & -3628.8 \\
\hline N. obs. & & 3120 & 3120 & 3120 & 3120 & 3120 & 3120 \\
\hline
\end{tabular}

Notes: as in Table 1. Each regression has been run controlling for regional characteristics and sector dummies which, in order to save space, are not included in the table, but are available from the authors upon request. 
Table 5. Simulation results. Percentage increases in FDI in Italian regions if regressors were set equal to the average of $E U$ countries other than Italy, period 1997-99

\begin{tabular}{lcccccc}
\hline & Italy & North-West & Lombardy & North-East & Centre & South \\
\hline Market size & 7.62 & -2.59 & -19.75 & -6.96 & 4.74 & 34.81 \\
Market potential & 9.19 & -4.24 & -3.46 & 0.91 & 1.1 & 26.02 \\
Wage & -24.44 & -5.17 & -4.08 & -18.01 & -17.81 & -37.8 \\
Unemployment & 0.17 & -0.55 & -1.22 & -1.48 & -0.51 & 0.88 \\
R\&D intensity & 6.34 & 2.01 & 4.21 & 9.71 & 4.1 & 9.57 \\
Schooling & 5.57 & 5.72 & 6.60 & 5.55 & 5.06 & 5.66 \\
Transport infrastructures & 6.03 & 5.83 & 4.48 & 6.22 & 5.16 & 6.88 \\
\hline
\end{tabular}

Note: The simulations are carried out with the estimates obtained by a regression which included all regressors of model (14) in Table 3, except the dummy for Italian regions 